\title{
Article
}

\section{Biodiversity of AM Fungi in Coffee Cultivated on Eroded Soil}

\author{
Liliana Lara-Capistran ${ }^{1}$, Ramon Zulueta-Rodriguez ${ }^{1}$, Bernardo Murillo-Amador ${ }^{2}$ (D), Pablo Preciado-Rangel ${ }^{3}$ (D), \\ Danis M. Verdecia-Acosta ${ }^{4}$ (D) and Luis G. Hernandez-Montiel ${ }^{2, *(D)}$
}

1 Facultad de Ciencias Agrícolas, Universidad Veracruzana, 91090 Xalapa, Veracruz, Mexico; llaracapistran@gmail.com (L.L.-C.); rzulueta36@hotmail.com (R.Z.-R.)

2 Centro de Investigaciones Biológicas del Noroeste, 23096 La Paz, Baja California Sur, Mexico; bmurillo04@cibnor.mx

3 Tecnológico Nacional de México-Instituto Tecnológico de Torreón, 27170 Torreón, Coahuila, Mexico; ppreciador@yahoo.com.mx

4 Facultad de Ciencias Agropecuarias, Universidad de Granma, 85100 Bayamo, Granma, Cuba; dverdeciaacosta@gmail.com

* Correspondence: lhernandez@cibnor.mx

Citation: Lara-Capistran, L.;

Zulueta-Rodriguez, R.;

Murillo-Amador, B.; Preciado-Rangel P.; Verdecia-Acosta, D.M.;

Hernandez-Montiel, L.G. Biodiversity of AM Fungi in Coffee Cultivated on Eroded Soil. Agronomy 2021, 11, 567. https://doi.org/10.3390/ agronomy 11030567

Received: 10 February 2021

Accepted: 10 March 2021

Published: 17 March 2021

Publisher's Note: MDPI stays neutral with regard to jurisdictional claims in published maps and institutional affiliations.

Copyright: (c) 2021 by the authors. Licensee MDPI, Basel, Switzerland. This article is an open access article distributed under the terms and conditions of the Creative Commons Attribution (CC BY) license (https:// creativecommons.org/licenses/by/ $4.0 /)$.

\begin{abstract}
Arbuscular mycorrhizal fungi (AMFs) play an important role in soil improvement, leading to the enhanced growth and yield of the host plants. The diversity, abundance, and richness of AMFs were evaluated in eight coffee plantations (Coffea arabica L.) with different erosion degrees. The results indicated that 26 AMFs morphotypes scattered across four genera were recovered and included five species. Funneliformis species were the most dominant representatives of the total isolates followed by Claroideoglomus, Rhizoglomus, Gigaspora, Acaulospora, Glomus, Diversispora, Septoglomus, and Scutellospora. The highest diversity and richness were found in non-eroded agroecosystems, followed by sites with a minimum erosion, and the lowest values were reported within the highly eroded agroecosystems. These results suggest that eroded soil affects AMF fungi, creating the need to carry out studies that allow for the implementation of cultural practices where biodiversity and soil are preserved.
\end{abstract}

Keywords: arbuscular mycorrhizal fungi; Coffea arabica; richness; Shannon-Weaver index

\section{Introduction}

Arbuscular mycorrhizal fungi (AMFs) are a category of obligate biotrophs, which is a mutualistic symbiotic association with the roots of most terrestrial plants [1,2] and are a major factor contributing to the maintenance of plant biodiversity and to ecosystem functioning $[3,4]$. AMFs play a vital role in improving plant growth, nutrient absorption and uptake, and tolerance to variety of biotic and abiotic stresses [5,6]. In this mutualistic symbiotic relationship between AMFs and plants, the fungi receive photosynthetically derived carbon compounds, and the plants have increased access to mineral nutrients and water $[7,8]$.

The occurrence of cosmopolitan AMFs suggests that these fungi are adaptable in terms of environmental conditions and in terms of an extensive host range $[9,10]$. Nevertheless, soil disturbance and erosion tend to reduce native AMF spore density, diversity, and infective potential [11,12], altering the pivotal role and critical link between plants and other rhizosphere microbial activities [13]. Moreover, the AMF role in maintaining soil structure and aggregation of particles improve important physical properties such as aeration, porosity, plant water availability, and nutrient supply and facilitate root penetration $[14,15]$.

Considering the beneficial effects of AMFs on plant performance and soil health, it is evident that AMF symbiosis can play a key role in guaranteeing an adequate terrestrial ecosystem functioning [16] and plant productivity in emerging systems of sustainable agriculture [17]. Recent studies reported that AMFs are a living bridge for the translocation 
of nutrients from soil to plant roots, and carbon from roots to the soil by an extensive intraradical and extraradical hyphal network $[5,7,8]$. Additionally, AMF symbiosis stimulates leaf gas exchange parameters, e.g., the net photosynthetic rate, the stomatal conductance, the intercellular $\mathrm{CO}_{2}$ concentration, the transpiration rate, the carbon exchange rate, chlorophylls biosynthesis, leaf $\mathrm{N}$ and $\mathrm{P}$ accumulation, and carbohydrate biosynthesis, and thus improves plant growth and yields [2,7]. To further understand the mycorrhizal dynamic in ecosystem output and forest regeneration, it is imperative to know how soil disturbance tillage practices affect mycorrhizal propagules and its activities [18,19].

Worldwide, a plant crop that is increasingly subjected to large variation exploitation for commercial production purposes is the coffee agroecosystem [20]. Plantations are managed in a variety of ways, which determines the yield, fruit quality, deterioration, or conservation of the natural resources and associated ecosystem services, as well as the richness and microflora of below-ground activity and soil biota in general. This is also affected in bare soil and/or when monocultures are pre-dominant [21]. One of the effects of coffee plantations is the contribution to the loss of large volumes of soil, which has been reported with the opening of natural areas for agricultural purposes in sites with a pronounced slope and high erosive risk. According to Loreto et al. [22], in coffeeproducing countries, a gradual and systematic change of land use has prevailed since the late nineteenth century, to such an extent that, in the period 1984-2000, an advanced level of soil erosion was registered, ca. $40 \%$. The aim of this study was to determinate the diversity of AMFs in eroded soils with coffee (Coffea arabica L.).

\section{Materials and Methods}

\subsection{Study Area}

The study sites were located in an area of $81,000 \mathrm{~m}^{2}$ of Teocelo, Veracruz, Mexico $\left(19^{\circ} 24^{\prime} \mathrm{E} ; 96^{\circ} 58^{\prime} \mathrm{W}\right)$. The climate is humid and temperate, where the annual precipitation varies between 1500 to $2000 \mathrm{~mm}$, with an average annual temperature of $18-20^{\circ} \mathrm{C}$. The predominant soils are classified as orthic Acrisol in the FAO 1974 System, characterized by a light-colored surface layer, low in organic matter (ochric A horizon) and with a low argillic $B$ horizon. Fertility variables are according to their slope of degree and depth. The nitrogen, phosphate, and potassium are often reduced. There are also humic Andosols with a dark-colored surface layer rich in organic matter, but the soil is generally acidic and poor in nutrients (umbric B horizon).

Additionally, some chemical properties of the soil are presented in Table 1. Eight coffee plantations (16 years ago) with different erosion degrees were sampled. The sites EroC1-3, EroC2-3, and EroC3-3 present moderate erosion, a vegetation stratum occupied by herbs at steep slopes $(\geq 85 \%)$, and a program of plant rejuvenation; applications of herbicides are made (glyphosates) three times a year with three fertilizations a year of 17-17-17 (content: $17 \%$ nitrogen, $17 \%$ phosphorus, and $17 \%$ potassium).

Table 1. Chemical soil parameters at field sites with different erosion degrees.

\begin{tabular}{cccccccc}
\hline \multirow{2}{*}{ Site } & $\mathbf{p H}$ & \multirow{2}{*}{ Organic Matter (\%) } & $\mathbf{N}(\%)$ & $\mathbf{P}(\mathbf{p p m})$ & \multicolumn{3}{c}{$\mathbf{\text { meq 100.g }}$} \\
\cline { 5 - 7 } & & & & & $\mathbf{K}$ & $\mathbf{C a}$ & $\mathbf{M g}$ \\
\hline 1. EroC1-3 & 5.2 & 7.77 & 0.39 & 4.0 & 0.03 & 3.2 & 2.47 \\
2. EroC2-3 & 4.5 & 7.91 & 0.40 & 8.0 & 0.02 & 2.7 & 5.0 \\
3. EroC3-3 & 4.6 & 7.10 & 0.36 & 7.0 & 0.025 & 3.37 & 3.96 \\
4. SevEroC1-3 & 5.0 & 1.76 & 0.36 & 5.0 & 0.02 & 1.9 & 1.88 \\
5. SevEroC2-3 & 4.9 & 1.0 & 0.36 & 11.0 & 0.02 & 3.32 & 1.92 \\
6. SevEroC3-3 & 4.7 & 0.90 & 0.21 & 13.0 & 0.051 & 3.48 & 2.6 \\
7. MinEroC & 4.6 & 7.10 & 0.36 & 21.0 & 0.05 & 2.25 & 2.92 \\
8. NonEroC & 4.8 & 7.10 & 0.49 & 4.0 & 0.06 & 4.0 & 2.39 \\
\hline
\end{tabular}

The sites SevEroC1-3, SevEroC2-3, and SevEroC3-3 have high erosion without a herb stratum or bare soil and have steep slopes $(\geq 85 \%)$. They also present programs for plant 
rejuvenation, applications of herbicides such as glyphosates, and three applications of fertilizers a year of 20-10-10 (content: 20\% nitrogen, 10\% phosphorus, and 10\% potassium), basic salts $\left(\mathrm{CaCO}_{3}\right)$, and 17-17-17. The site MinEroC presented minimum erosion with a very gentle slope of $2-4 \%$. It did not include an application of pesticides but did include snipping herbs three times a year (utilizing cutting tools) and three fertilizations a year of 17-17-17. The site NonEroC presented an overhead cover of dense herbaceous vegetation without erosion and a very gentle slope of $2-4 \%$. Applications of pesticides were not made; however, basic fertilizations of 17-17-17 were done by hand three times a year (Table 2). All the plantations were 16 years old at the time.

Table 2. Principal agricultural management practices and standing crops at the sampling data for field sites.

\begin{tabular}{|c|c|c|c|c|c|c|}
\hline & Site & Abbreviation & $\begin{array}{c}\text { Topographic and } \\
\text { Slope }\end{array}$ & $\begin{array}{c}\text { Chemical } \\
\text { Fertilization }\end{array}$ & $\begin{array}{c}\text { Pest } \\
\text { Management }\end{array}$ & $\begin{array}{c}\text { Crop } \\
\text { Management }\end{array}$ \\
\hline $\begin{array}{l}1 . \\
2 . \\
3 .\end{array}$ & $\begin{array}{l}\text { Coffee on } \\
\text { eroded soil }\end{array}$ & $\begin{array}{l}\text { EroC1-3 } \\
\text { EroC2-3 } \\
\text { EroC3-3 }\end{array}$ & $\begin{array}{l}\text { Steep slope }(\geq 85 \%) \\
\text { and herb strata }\end{array}$ & No & \multirow{2}{*}{$\begin{array}{l}\text { Chemical } \\
\text { control }\end{array}$} & \multirow{3}{*}{$\begin{array}{c}\text { Rejuvenation } \\
\text { program }\end{array}$} \\
\hline $\begin{array}{l}4 . \\
5 . \\
6 .\end{array}$ & $\begin{array}{c}\text { Coffee on } \\
\text { severe eroded } \\
\text { soil }\end{array}$ & $\begin{array}{l}\text { SevEroC1-3 } \\
\text { SevEroC2-3 } \\
\text { SevEroC3-3 }\end{array}$ & Steep slope $(\geq 85 \%)$ & $\begin{array}{l}20-10-10 \\
17-17-17 \\
\mathrm{CaCO}_{3}\end{array}$ & & \\
\hline 8. & $\begin{array}{l}\text { Coffee on very } \\
\text { low eroded soil }\end{array}$ & NonEroC & $\begin{array}{c}\text { Very gentle slope } \\
(2-4 \%) \text { with manual } \\
\text { weeding control } \\
\text { Very gentle slope } \\
(2-4 \%) \text { with dense } \\
\text { herbaceous stratum }\end{array}$ & $17-17-17$ & $\begin{array}{l}\text { Organic } \\
\text { control }\end{array}$ & \\
\hline
\end{tabular}

\subsection{Sample Collection}

The soil samples were randomly collected (five replications per field site). This period corresponds to the end of the rainy season in the region (between September and October). In total, 40 core soil samples were collected from a depth of 5-7 cm. These included AMF spore quantifications, a determination of the number of species, and a determination of several chemical soil properties, such as $\mathrm{pH}$ and organic matter (Table 1). The soil parameters were measured according to the following methods: $\mathrm{pH}$ (potentiometer), soil texture (Bouyoucos-Day method), organic matter [23], nitrogen (micro-Kjeldahl method), phosphorus (Bray P1-Kitson Mellon method), potassium and sodium (flomemetric method), calcium and magnesium [24], and electrical conductivity (saturation extract).

\subsection{Isolation and Identification of AMF Spores}

For the isolation of Glomalean spores from the soil samples, a wet sieving and decanting procedure was followed [25]. Briefly, $50 \mathrm{~g}$ of rhizospheric soil was dissolved in $1000 \mathrm{~mL}$ of water, and the coarse particles were allowed to settle for $5 \mathrm{~min}$. The soil suspension was then decanted through stacked sieves kept in descending pore size $(177-45 \mu \mathrm{m})$. The same step was repeated three times so that the majority of spores were recovered from the soil. The floating debris on the sieves were collected into $50 \mathrm{~mL}$ centrifuge tubes and spun for 5 min (1800 rpm) using a bench-top Sol-Bat centrifuge. The supernatant was discarded, and the pellet was re-suspended in a sucrose solution $\left(480 \mathrm{~g} \cdot \mathrm{L}^{-1}\right)$. The suspension was centrifuged for 35-60 s (1800 rpm). Finally, the resulting supernatant was passed through a $45 \mu \mathrm{m}$ sieve, rinsed with tap water, and transferred to Petri dishes [26].

Spores were collected under a dissecting microscope, using ultra-fine forceps or glass micropipettes, and were mounted on slides with polyvinyl lactic acid-glycerol (PVLG; [27]). Spores were counted in the slides previously marked with a grid using a compound microscope and were grouped according to their morphological characteristics. Permanent slides were prepared for each different spore morphotype with PVLG media and Melzer's 
reagent $(1: 1, v / v)$ [28]. After the uniformity of the morphological groups was confirmed under the optical microscope, and different morphotypes were identified to the genus level and, when possible, to the species level. Spore identification was based mainly on spore size, color, sub-cellular structures (wall structure and flexible inner walls), hyphal attachment, and the mode of spore germination $[26,29,30]$.

After spore identification, richness was calculated $(R=$ the number of species found in the sample), and the Shannon-Weaver index was calculated as an additional measure of AMF diversity spores identified per site, as it combines two components of diversity, i.e., species richness and evenness [31].

\subsection{Statistical Analysis}

Data were processed by a one-way variance analysis (ANOVA) using the statistical package STADISTICA (StatSoft, Tulsa, OK). The post hoc LSD Fisher test $(p<0.05)$ was used for a comparison of means. A hierarchical cluster analysis (HCA) was applied to determine the relationship between field sites and replicate plots of field sites in AMF diversity species. The measure of similarity (conglomerate analysis) used was the Euclidean distance as a measure of similarity between morphospecies, where the Euclidean distance quantifies the identity between units of analysis that have been evaluated in a set of (quantitative) variables.

\section{Results}

\subsection{AMF Identification}

Twenty-six genera of AMFs were identified in all field sites with coffee (Figure 1). The genera identified were Claroideoglomus, Funneliformis, Rhizoglomus, Septoglomus, Diversispora, Glomus, Acaulospora, Gigaspora, and Scutellospora (Figure 2). The most frequent AMF species was found at NonEroC with 25 species and MinEroc with 12 species (Table 3). SevEroC1-3, SevEroC2-3, and evEroC3-3 had the lowest number of AMF species.

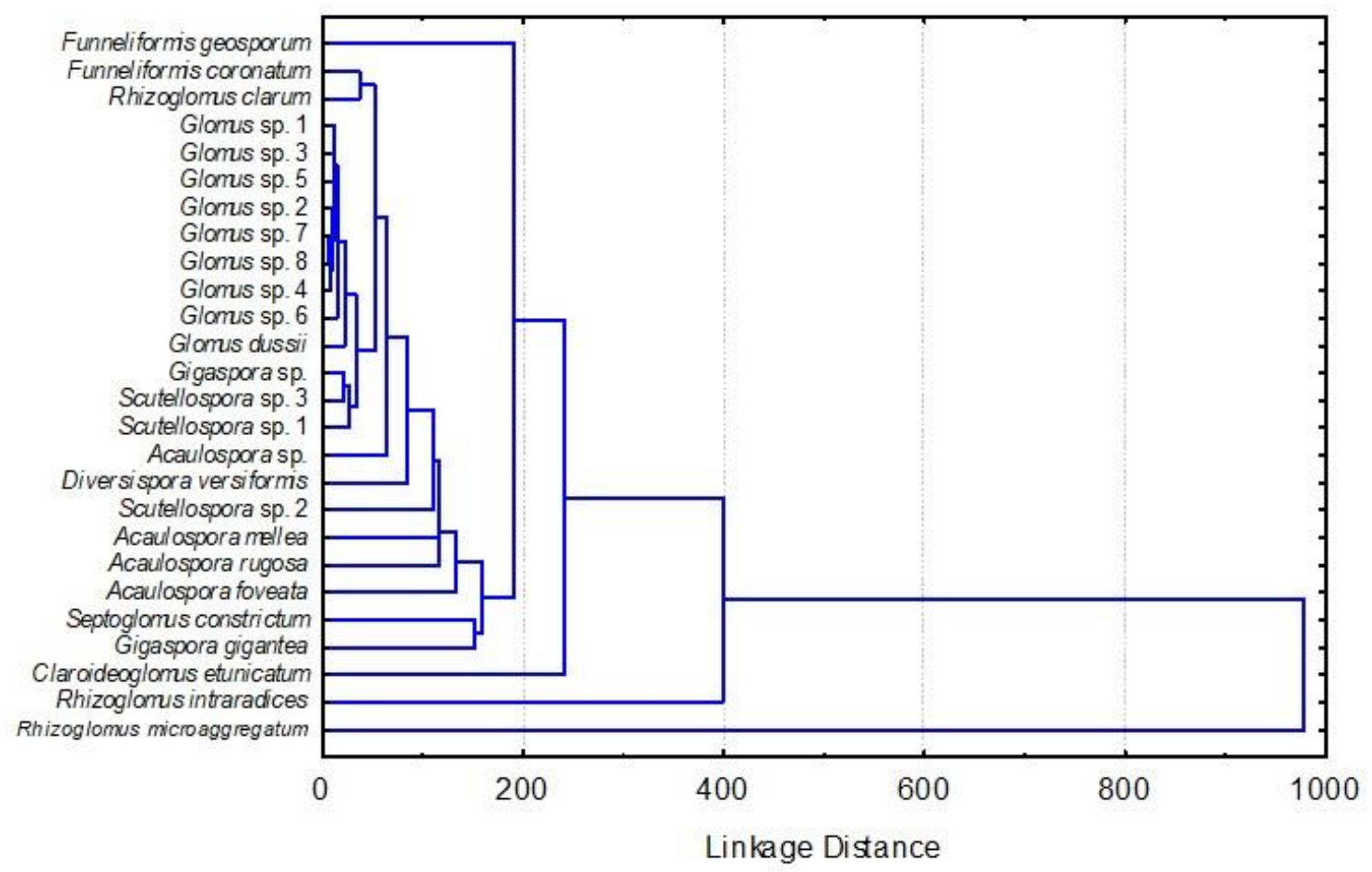

Figure 1. Dendrogram of the hierarchical conglomerate analysis performed using the arbuscular mycorrhizal fungi morpho-species groups. 

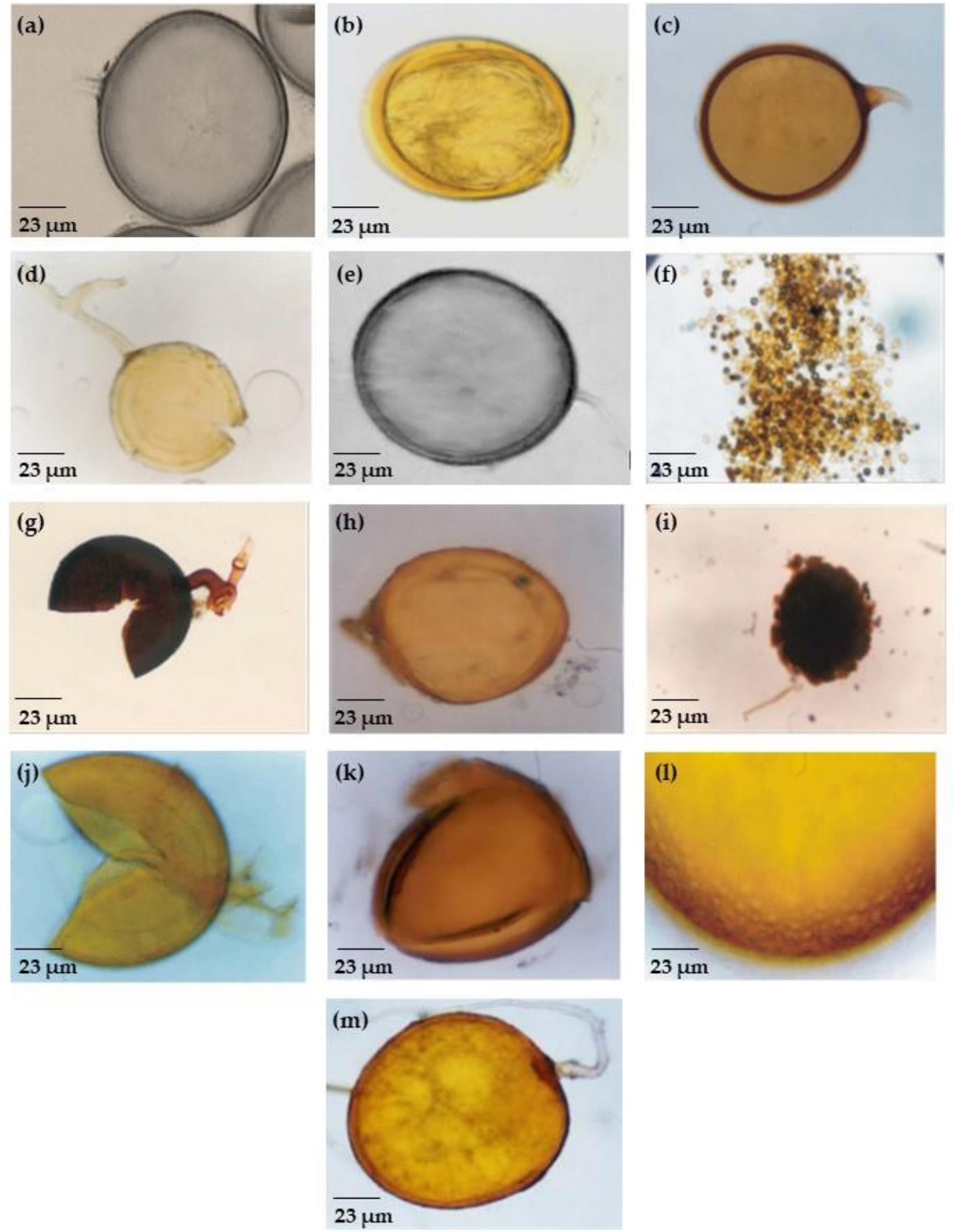

Figure 2. Morphology of some AMF species isolated from coffee roots. (a) C. etunicatum, (b) F. geosporum, (c) F. coronatum, (d) R. clarum, (e) R. intraradices, (f) R. microaggregatum, (g) S. constrictum, (h) D. versiformis, (i) Gl. dussii, (j) A. rugosa, (k) A. mellea, (1) A. foveata, and (m) G. gigantea. 
Table 3. Spore abundance of AMF species found at field sites with coffee.

\begin{tabular}{|c|c|c|c|c|c|c|c|c|}
\hline \multirow{2}{*}{ Species } & \multicolumn{8}{|c|}{ Spore Abundance of AMFs-No. of Spores (\% Spores per Site) } \\
\hline & EroC1-3 & ErocC2-3 & EroC3-3 & SevEroC1-3 & SevEroC2-3 & SevEroC3-3 & MinEroC & NonEroC \\
\hline C. etunicatum & - & $58(37.6)$ & - & - & - & - & $93(40.9)$ & $2(0.2)$ \\
\hline F. geosporum & $30(39.4)$ & 85 (55.2) & $64(48.8)$ & $47(23.2)$ & $22(14)$ & _- & $28(12.3)$ & $63(8.7)$ \\
\hline F. coronatum & $4(5.2)$ & - & - & - & - & - & $2(0.8)$ & $9(1.2)$ \\
\hline R. clarum & - & _- & - & _- & _- & _- & - & $6(0.8)$ \\
\hline R. intraradices & $17(22.3)$ & $4(2.6)$ & 19 (14.5) & - & - & - & $8(3.5)$ & $29(4)$ \\
\hline R. microaggregatum & $20(26.3)$ & - & - & $56(27.8)$ & - & - & $50(22.1)$ & $451(62.2)$ \\
\hline S. constrictum & - & $4(2.6)$ & - & - & - & - & - & $6(0.8)$ \\
\hline D. versiformis & - & $3(1.9)$ & - & - & - & - & - & $5(0.7)$ \\
\hline Gl. dussii & - & - & $1(0.8)$ & - & - & - & - & $2(0.2)$ \\
\hline Gl. sp. 1 & $5(6.5)$ & - & - & - & - & - & - & $2(0.2)$ \\
\hline Gl. sp. 2 & - & _- & _- & - & - & - & - & $3(0.4)$ \\
\hline Gl. sp. 3 & - & - & - & - & - & - & $2(0.8)$ & - \\
\hline Gl. sp. 4 & - & - & - & - & - & - & - & $2(0.2)$ \\
\hline Gl. sp. 5 & - & - & - & - & - & - & $1(0.4)$ & $2(0.2)$ \\
\hline Gl. sp. 6 & - & - & - & - & - & - & $2(0.8)$ & $2(0.2)$ \\
\hline Gl. sp. 7 & - & - & - & - & - & _- & - & $3(0.4)$ \\
\hline Gl. sp. 8 & - & - & - & - & - & - & $1(0.4)$ & $3(0.4)$ \\
\hline A. rugosa & - & - & $12(9.1)$ & - & $21(13.3)$ & $28(28.2)$ & $31(13.6)$ & $42(5.8)$ \\
\hline A. mellea & - & - & - & - & - & - & - & $4(0.5)$ \\
\hline A. foveata & - & - & - & - & - & - & $6(2.6)$ & $5(0.7)$ \\
\hline Acaulospora sp. & - & - & - & - & - & - & - & $3(0.4)$ \\
\hline G. gigantea & - & - & $35(26.7)$ & $99(49)$ & $114(72.6)$ & $71(71.7)$ & $3(1.3)$ & $66(9.1)$ \\
\hline Gigaspora sp. & - & - & - & - & - & - & - & $4(0.5)$ \\
\hline Scutellospora sp. 1 & - & - & - & - & - & - & - & $3(0.4)$ \\
\hline Scutellospora sp. 2 & _- & - & - & - & - & _- & _- & $4(0.5)$ \\
\hline Scutellospora sp. 3 & - & - & - & - & - & - & - & $4(0.5)$ \\
\hline
\end{tabular}

\subsection{AMF Diversity (Shannon-Weaver Index)}

The highest Shannon-Weaver diversity index was observed at NonEroC and the lowest indexes were quantified at the sites with different erosion degrees (Figure 3). NonEroC, with overhead cover of dense herbaceous vegetation and without erosion, showed the highest AMF diversity.

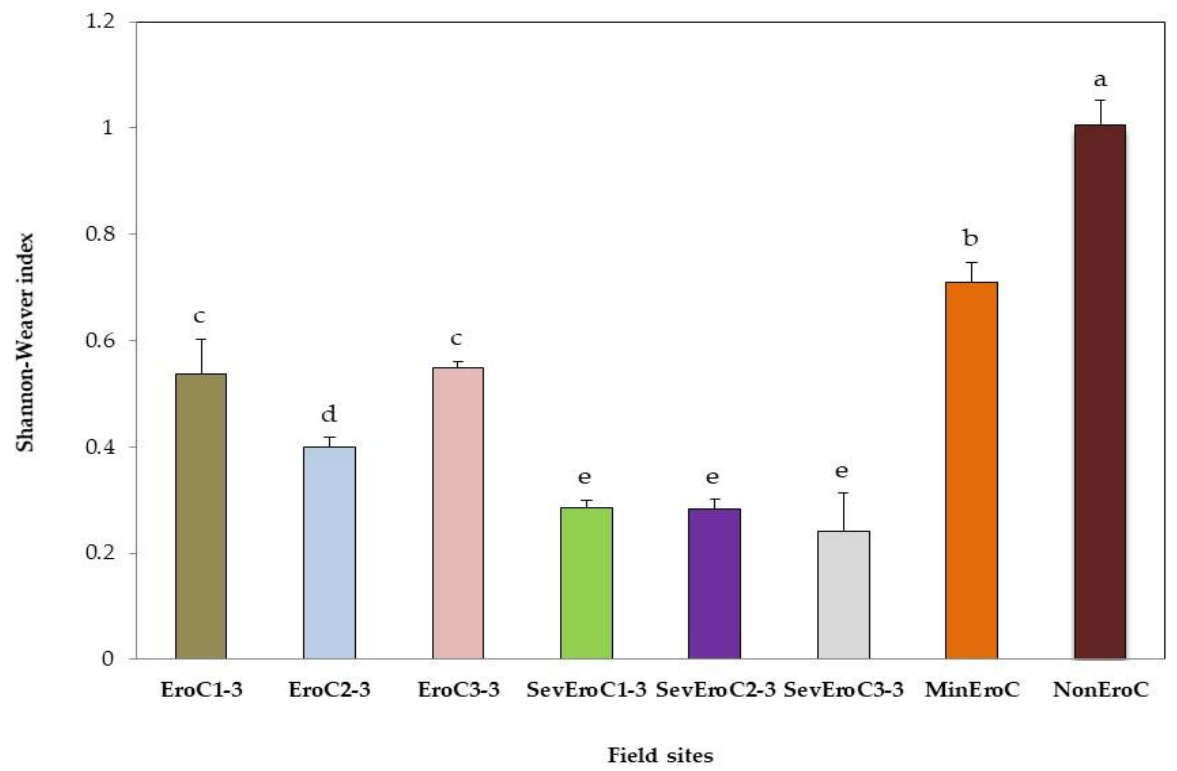

Figure 3. AMF diversity (Shannon-Weaver index) in field sites with different erosion degrees. Each column color indicates a different field site with coffee. Columns with the same letter are not significantly different according to the post hoc LSD Fisher test at $p<0.05$. 


\subsection{AMF Species Richness}

A low species richness of AMFs occurred in sites with severe erosion and without herb strata (Figure 4). However, the highest AMF species richness (25 morpho-species) were found in a non-significant erosion site (NonEroC) with a carpet of annual and perennial herbaceous plants.

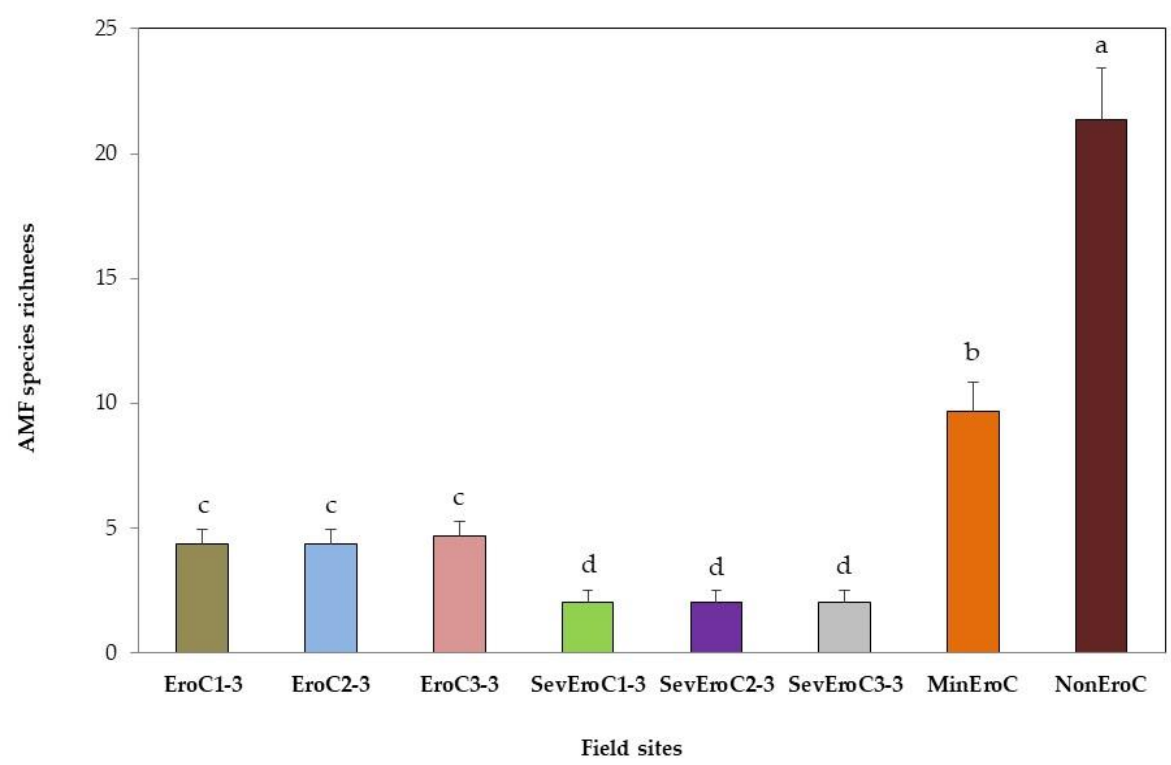

Figure 4. Species richness of AMFs in field sites with different erosion degrees. Each column color indicates a different field site with coffee. Columns with the same letter are not significantly different according to the post hoc LSD Fisher test at $p<0.05$.

\section{Discussion}

Arbuscular mycorrhizal fungi (AMFs) are important components of soil microbial communities. They improve soil fertility and are associated with the roots of most plants [2,23]. The previous studies reported that AMFs had a great potential to increase productivity in a variety of plants, including coffee [32,33], and induce resistance to herbivores [34] and phytopathogens [35]. Additionally, AMFs play an important role in nutrient recycling and transformation, including $\mathrm{N}, \mathrm{P}, \mathrm{K}, \mathrm{C}$, and micronutrients to accomplish plant demand, thus leading to increased growth and development $[7,36]$. In the soil, the AMFs contribute to the stability of the aggregates $[37,38]$ through accumulation in the soil of glomalin-related soil proteins (GRSPs), a component of the hyphal cell wall [39].

However, the benefic effects of AMFs on plants decreases due to soil nutrients, $\mathrm{pH}$, salinity, soil hydrologic properties, and topography, among others [40,41], affecting these parameters the diversity, richness, and density of AMFs in this study [42]. The absence or decrease in AMFs in the soil can cause negative effects on the establishment and productivity of the plant community [43].

Pesticides play a role in pest control, but they affect the microbial community. Only in two sites (MinEroC and NonEroC) was the control of pests achieved with organic products. The remaining sites applied pesticides, which limit the pre-symbiotic phase (spore germination, germ tube elongation, and hyphal branching, among others) and the active symbiosis of AMFs within the host's roots and its extraradical mycelium in the surrounding soil. The application of pesticides affects the establishment of AMFs in the field, so their use in crop management should be minimized [44]. Moreover, the application of organic products increased the microbial community in the soil [45]. Another practice that affects AMFs is the use of herbicides, which reduces invasive plants in the field, but the clear impact on AMFs is observed when an herbicide is applied directly to a host plant [46]. 
Chemical fertilizers cause large surpluses, mainly $\mathrm{N}$ and $\mathrm{P}$, which reduce the diversity of AMFs in the soil [47]. The coffee soils with a greater eroded soil degree lack the vegetation covering of herbaceous plants and the monoculture prevails as the only host, which limits the AMF presence to only one host. Some studies have shown that this decreases mycorrhizal diversity species [48].

Additionally, studies have shown that soil that has been transformed from natural forest to agricultural land has lost AMF diversity [31]. It is well known that, in soil with a higher degree of erosion (SevEroC1-3, SevEroC2-3, and SevEroC3-3), the AMF species will be lower, as shown in Figure 1; however, at these sites, fungus richness was lower than it was in the non-eroded site (NonEroC), where it was significantly higher (Figure 3). $R$. microaggregatum was the most abundant, followed by R. clarum and D. versiformis (Table 1 ). These genera have been previously reported as the genus Glomus in coffee plantations in Ethiopia [49], Mexico [50], and Brazil [51].

The cluster analysis shows that Glomus sp. 1 and Scutellospora sp. 1 have characteristics that make them similar to each other, given the minimal distances between them (Figure 2). This type of analysis shows the similarity in AMF species composition [31]. These results agree with de Assis et al. [52], where there is a low diversity of phylum Glomeromycota in disturbed and eroded areas. More studies are needed to determine the effects of human activities, soil, and climate factors on AMF communities.

\section{Conclusions}

In this study, 26 morpho-species belonging to 4 of the 13 known genera were identified. Among them were Funneliformis and Claroideoglomus, which were most frequent. The diversity, abundance, and richness of AMFs in highly eroded coffee agroecosystems were low, with an outstanding presence of G. gigantea and A. rugosa. In non-eroded sites, the AMF diversity, abundance, and richness were higher. The identification of AMF species such as F. coronatum, G. dussii, D. versiformis, and A. rugosa, among others, shows the importance of these studies in the area of agroecosystems, and even more so in highly disturbed systems. In subsequent studies, the diversity of species should be evaluated at the molecular level, as should the participation of these mycorrhizal species in the formation of soil particles and the stability of ecosystems.

Author Contributions: Conceptualization, L.L.-C., R.Z.-R. and L.G.H.-M.; methodology, L.L.-C. and P.P.-R.; formal analysis, R.Z.-R. and B.M.-A.; investigation, L.L.-C. and B.M.-A.; writing-original draft preparation, R.Z.-R., D.M.V.-A. and L.G.H.-M.; writing-review and editing, B.M.-A. and L.G.H.-M.; visualization, P.P.-R.; supervision, R.Z.-R. and B.M.-A.; project administration, L.L.-C., D.M.V.-A. and R.Z.-R.; funding acquisition, L.L.-C. All authors have read and agreed to the published version of the manuscript.

Funding: This research received no external funding.

Institutional Review Board Statement: Not applicable.

Informed Consent Statement: Not applicable.

Data Availability Statement: Not applicable.

Acknowledgments: We are thankful to Chris Walker and Dra. Lucia Varela F. for technical assistance in identifying spores of mycorrhizal fungus.

Conflicts of Interest: The authors declare no conflict of interest.

\section{References}

1. Giovannini, L.; Sbrana, C.; Avio, L.; Turrini, A. Diversity of a phosphate transporter gene among species and isolates of arbuscular mycorrhizal fungi. FEMS Microbiol. Lett. 2020, 367, 24. [CrossRef] [PubMed]

2. Powell, J.R.; Rillig, M.C. Biodiversity of arbuscular mycorrhizal fungi and ecosystem function. New Phytol. 2018, 220, 1059-1075. [CrossRef] [PubMed] 
3. Victorino, Í.M.M.; Voyron, S.; Caser, M.; Orgiazzi, A.; Demasi, S.; Berruti, A.; Scariot, V.; Bianciotto, V.; Lumini, E. Metabarcoding of soil fungal communities associated with alpine field-grown saffron (Crocus sativus L.) inoculated with am fungi. J. Fungi 2021, 7, 45. [CrossRef] [PubMed]

4. Lutzoni, F.; Nowak, M.D.; Alfaro, M.E.; Reeb, V.; Miadlikowska, J.; Krug, M.; Arnold, A.E.; Lewis, L.A.; Swofford, D.L.; Hibbett, D.; et al. Contemporaneous radiations of fungi and plants linked to symbiosis. Nat. Commun. 2018, 9, 5451. [CrossRef] [PubMed]

5. Liu, L.; Li, D.; Ma, Y.; Shen, H.; Zhao, S.; Wang, Y. Combined application of arbuscular mycorrhizal fungi and exogenous melatonin alleviates drought stress and improves plant growth in tobacco seedlings. J. Plant Growth Regul. 2020, 1-14. [CrossRef]

6. Diagne, N.; Ngom, M.; Djighaly, P.I.; Fall, D.; Hocher, V.; Svistoonoff, S. Roles of arbuscular mycorrhizal fungi on plant growth and performance: Importance in biotic and abiotic stressed regulation. Diversity 2020, 12, 370. [CrossRef]

7. Jacott, C.N.; Murray, J.D.; Ridout, C.J. Trade-offs in arbuscular mycorrhizal symbiosis: Disease resistance, growth responses and perspectives for crop breeding. Agronomy 2017, 7, 75. [CrossRef]

8. Cavagnaro, T.R.; Bender, S.F.; Asghari, H.R.; van der Heijden, M.G. The role of arbuscular mycorrhizas in reducing soil nutrient loss. Trends Plant Sci. 2015, 20, 283-290. [CrossRef]

9. Guerrero-Galán, C.; Houdinet, G.; Calvo-Polanco, M.; Bonaldi, K.E.; Garcia, K.; Zimmermann, S.D. The role of plant transporters in mycorrhizal symbioses. Adv. Bot. Res. 2018, 87, 303-342.

10. Chen, M.; Arato, M.; Borghi, L.; Nouri, E.; Reinhardt, D. Beneficial services of arbuscular mycorrhizal fungi-From ecology to application. Front. Plant Sci. 2018, 9, 1270. [CrossRef]

11. Stürmer, S.L.; Bever, J.D.; Morton, J.B. Biogeography of arbuscular mycorrhizal fungi (Glomeromycota): A phylogenetic perspective on species distribution patterns. Mycorrhiza 2018, 28, 587-603. [CrossRef]

12. Birhane, E.; Gebretsadik, K.F.; Taye, G.; Aynekulu, E.; Rannestad, M.M.; Norgrove, L. Effects of forest composition and disturbance on arbuscular mycorrhizae spore density, arbuscular mycorrhizae root colonization and soil carbon stocks in a dry afromontane forest in Northern Ethiopia. Diversity 2020, 12, 133. [CrossRef]

13. Hrynkiewicz, K.; Baum, C. The potential of rhizosphere microorganisms to promote the plant growth in disturbed soils. In Environmental Protection Strategies for Sustainable Development. Strategies for Sustainability; Malik, A., Grohmann, E., Eds.; Springer Science+Business: New York, NY, USA, 2011; pp. 35-64.

14. Al-Maliki, S.; Ebreesum, H. Changes in soil carbon mineralization, soil microbes, roots density and soil structure following the application of the arbuscular mycorrhizal fungi and green algae in the arid saline soil. Rhizosphere 2020, 14, 100203. [CrossRef]

15. Wang, Y.; Xing, D.; Luo, C.B.; Zhang, F.; Zhang, C.M. Arbuscular mycorrhizal fungal species identity governs plant water content and soil aggregation improvements under wet-dry climate conditions. Environ. Sci. Pollut. Res. 2020, 27, 37377-37383. [CrossRef]

16. Song, Z.; Bi, Y.; Zhang, J.; Gong, Y.; Yang, H. Arbuscular mycorrhizal fungi promote the growth of plants in the mining associated clay. Sci. Rep. 2020, 10, 2663. [CrossRef] [PubMed]

17. Johnson, N.C.; Gibson, K.S. Understanding multilevel selection may facilitate management of arbuscular mycorrhizae in sustainable agroecosystems. Front. Plant Sci. 2021, 11, 2316. [CrossRef] [PubMed]

18. Medeiros, A.S.; Goto, B.T.; Ganade, G. Ecological restoration methods influence the structure of arbuscular mycorrhizal fungal communities in degraded drylands. Pedobiologia 2021, 84, 150690. [CrossRef]

19. Van der Heijden, M.; Ohsowski, B.; Abbott, L.K.; Hart, M. Arbuscular mycorrhizal fungus responses to disturbance are contextdependent. Mycorrhiza 2017, 27, 431-440. [CrossRef]

20. House, G.L.; Bever, J.D. Disturbance reduces the differentiation of mycorrhizal fungal communities in grasslands along a precipitation gradient. Ecol. Appl. 2018, 28, 736-748. [CrossRef]

21. Cerda, R.; Allinne, C.; Gary, C.; Tixier, P.; Harvey, C.A.; Krolczyk, L.; Mathiot, C.; Clément, E.; Aubertot, J.N.; Avelino, J. Effects of shade, altitude and management on multiple ecosystem services in coffee agroecosystems. Eur. J. Agron. 2017, 82, 308-319. [CrossRef]

22. Loreto, D.; Esperón-Rodríguez, M.; Barradas, V.L. The climatic-environmental significance, status and socio-economic perspective of the grown-shade coffee agroecosystems in the central mountain region of Veracruz, Mexico. Investig. Geogr. 2017, 92, 1-14. [CrossRef]

23. He, F.; Tang, M.; Zhong, S.L.; Yang, R.; Huang, L.; Zhang, H.Q. Effects of soil and climatic factors on arbuscular mycorrhizal fungi in rhizosphere soil under Robinia pseudoacacia in the Loess Plateau, China. Eur. J. Soil Sci. 2016, 67, 847-856. [CrossRef]

24. Walkley, A.; Black, I.A. An examination of the Degtjareff method for determining soil organic matter, and a proposed modification of the chromic acid titration method. Soil Sci. 1934, 37, 29-38. [CrossRef]

25. Diehl, H.; Goetz, C.A.; Hach, C.C. The versenate titration for total hardness. J. Am. Water Works Assoc. 1950, 42, 40-48. [CrossRef]

26. Gerdemann, J.W.; Nicolson, T.H. Spores of mycorrhizal endogone species extracted from soil by wet sieving and decanting. Trans. Br. Mycol. Soc. 1963, 46, 235-244. [CrossRef]

27. Walker, C. Spore Extraction by Centrifugation-sugar Flotation; Biological Research and Imaging: New Milton, Hampshire, UK, 1997.

28. Koske, R.E.; Tessier, B. A convenient, permanent slide mounting medium. Newsl. Mycol. Soc. Am. 1983, $34,59$.

29. Brundrett, M.; Melville, L.; Peterson, L. Practical Methods in Mycorrhiza Research; Mycologue Publications: Ontario, CA, USA, 1994.

30. Schenck, N.C.; Perez, Y. Manual for the Identification of Mycorrhizal Fungi, 3rd ed.; Synergistic Publications; Gainesville: Gainesville, FL, USA, 1990.

31. Shi, N.N.; Gao, C.; Zheng, Y.; Guo, L.D. Arbuscular mycorrhizal fungus identity and diversity influence subtropical tree competition. Fungal Ecol. 2016, 20, 115-123. [CrossRef] 
32. Agnihotri, R.; Bharti, A.; Ramesh, A.; Prakash, A.; Sharma, M.P. Glomalin related protein and C16: $1 \omega 5$ PLFA associated with AM fungi as potential signatures for assessing the soil C sequestration under contrasting soil management practices. Eur. J. Soil Biol. 2021, 103, 103286. [CrossRef]

33. Aldrich-Wolfe, L.; Black, K.L.; Hartmann, E.D.; Shivega, W.G.; Schmaltz, L.C.; McGlynn, R.D.; Johnson, P.G.; Asheim, R.J.; Vink, S.N. Taxonomic shifts in arbuscular mycorrhizal fungal communities with shade and soil nitrogen across conventionally managed and organic coffee agroecosystems. Mycorrhiza 2020, 30, 513-527. [PubMed]

34. Formenti, L.; Rasmann, S. Mycorrhizal fungi enhance resistance to herbivores in tomato plants with reduced jasmonic acid production. Agronomy 2019, 9, 131. [CrossRef]

35. Zhang, Q.; Gao, X.; Ren, Y.; Ding, X.; Qiu, J.; Li, N.; Zeng, F.; Chu, Z. Improvement of Verticillium wilt resistance by applying arbuscular mycorrhizal fungi to a cotton variety with high symbiotic efficiency under field conditions. Int. J. Mol. Sci. 2018, 19, 241. [CrossRef]

36. Schütz, L.; Gattinger, A.; Meier, M.; Müller, A.; Boller, T.; Mäder, P.; Mathimaran, N. Improving crop yield and nutrient use efficiency via biofertilization-A global meta-analysis. Front. Plant Sci. 2018, 8, 2204. [CrossRef]

37. Lehmann, A.; Zheng, W.; Rillig, M.C. Soil biota contributions to soil aggregation. Nat. Ecol. Evol. 2017, 1, 1828-1835. [CrossRef] [PubMed]

38. Moitinho, M.R.; Fernandes, C.; Truber, P.V.; Marcelo, A.V.; Corá, J.E.; da Silva Bicalho, E. Arbuscular mycorrhizal fungi and soil aggregation in a no-tillage system with crop rotation. J. Plant Nutr. Soil Sci. 2020, 183, 482-491. [CrossRef]

39. Hossain, M.B. Glomalin and contribution of glomalin to carbon sequestration in soil: A review. Turk. J. Agric. Food Sci. Technol. 2021, 9, 191-196. [CrossRef]

40. Liu, M.; Shen, Y.; Li, Q.; Xiao, W.; Song, X. Arbuscular mycorrhizal fungal colonization and soil pH induced by nitrogen and phosphorus additions affects leaf C: N: P stoichiometry in chinese fir (Cunninghamia lanceolata) forests. Plant Soil. 2021, 1-20. [CrossRef]

41. Jones, S.L.; French, K. Soil nutrients differentially influence root colonisation patterns of AMF and DSE in Australian plant species. Symbiosis 2021, 83, 209-223. [CrossRef]

42. Tajik, S.; Ayoubi, S.; Lorenz, N. Soil microbial communities affected by vegetation, topography and soil properties in a forest ecosystem. Appl. Soil Ecol. 2020, 149, 103514. [CrossRef]

43. Koziol, L.; Bever, J.D. The missing link in grassland restoration: Arbuscular mycorrhizal fungi inoculation increases plant diversity and accelerates succession. J. Appl. Ecol. 2017, 54, 1301-1309. [CrossRef]

44. Hage-Ahmed, K.; Rosner, K.; Steinkellner, S. Arbuscular mycorrhizal fungi and their response to pesticides. Pest. Manag. Sci. 2019, 75, 583-590. [CrossRef]

45. Kakabouki, I.; Efthimiadou, A.; Folina, A.; Zisi, C.; Karydogianni, S. Effect of different tomato pomace compost as organic fertilizer in sweet maize crop. Commun. Soil Sci. Plant. Anal. 2020, 51, 2858-2872. [CrossRef]

46. Wilkes, T.I.; Warner, D.J.; Davies, K.G.; Edmonds-Brown, V. Tillage, Glyphosate and beneficial arbuscular mycorrhizal fungi: Optimising crop management for plant-fungal symbiosis. Agriculture 2020, 10, 520. [CrossRef]

47. Qin, Z.; Zhang, H.; Feng, G.; Christie, P.; Zhang, J.; Li, X.; Gai, J. Soil phosphorus availability modifies the relationship between AM fungal diversity and mycorrhizal benefits to maize in an agricultural soil. Soil Biol. Biochem. 2020, 144, 107790. [CrossRef]

48. Luo, X.; Su, X.; Cui, J.; Lou, Y.; Li, R.; Luo, X.; Zeng, Y.; Xu, Y.; Dong, J. Biodiversity of arbuscular mycorrhizal fungi in the drawdown zone of the three gorges reservoir under different fertilization histories. Ecol. Res. 2016, 31, 407-416. [CrossRef]

49. Verbruggen, E.; Xiang, D.; Chen, B.; Xu, T.; Rillig, M.C. Mycorrhizal fungi associated with high soil N:P ratios are more likely to be lost upon conversion from grasslands to arable agriculture. Soil Biol. Biochem. 2015, 86, 1-4. [CrossRef]

50. Muleta, D.; Assefa, F.; Nemomissa, S.; Granhall, U. Distribution of arbuscular mycorrhizal fungi spores in soils of smallholder agroforestry and monocultural coffee systems in southwestern Ethiopia. Biol. Fertil. Soils. 2008, 44, 653-659. [CrossRef]

51. Arias, R.M.; Heredia-Abarca, G.; Sosa, V.J.; Fuentes-Ramírez, L.E. Diversity and abundance of arbuscular mycorrhizal fungi spores under different coffee production systems and in a tropical montane cloud forest patch in Veracruz, Mexico. Agrofor. Syst. 2012, 85, 179-193. [CrossRef]

52. De Assis, D.M.A.; Oehl, F.; Gonçalves, C.M.; da Silva, D.K.A.; da Silva, G.A. Community structure of arbuscular mycorrhizal fungi in fluvial and maritime dunes of Brazilian Northeast. Appl. Soil Ecol. 2016, 108, 136-146. [CrossRef] 